\title{
5S and 5W2H Tools Applied to Research Laboratories: Experience from Instituto Carlos Chagas - FIOCRUZ/PR for Cell Culture Practices
}

\author{
Crisciele Kuligovski ${ }^{1,2}$
}

https://orcid.org/0000-0002-8418-9378

\author{
Anny Waloski Robert ${ }^{1}$ \\ https://orcid.org/0000-0002-7837-2790
}

Camila Maria Oliveira de Azeredo ${ }^{3}$

https://orcid.org/0000-0002-7521-1350

\author{
João Antonio Palma Setti ${ }^{4}$ \\ https://orcid.org/0000-0003-0659-1297
}

\section{Alessandra Melo de Aguiar $1,5 *$ \\ https://orcid.org/0000-0002-6167-8478}

\begin{abstract}
${ }^{1}$ Carlos Chagas Institute - FIOCRUZ Paraná, Basic Stem Cell Biology Laboratory, Curitiba, Paraná, Brazil; ${ }^{2}$ Carlos Chagas Institute - FIOCRUZ Paraná, Cell Culture Laboratory, Curitiba, Paraná, Brazil; ${ }^{3}$ Carlos Chagas Institute FIOCRUZ Paraná, Quality Warranty Core, Curitiba, Paraná, Brazil; ${ }^{4}$ Federal University of Technology - Paraná (UTFPR), Department of Biomedical Engineering, Curitiba, Paraná, Brazil; ${ }^{5}$ Carlos Chagas Institute - FIOCRUZ Paraná, Technologic Core Facilities: Bioassays in alternative methods in cytotoxicity, Curitiba, Paraná, Brazil.
\end{abstract}

Editor-in-Chief: Alexandre Rasi Aoki

Associate Editor: Alexandre Rasi Aoki

Received: 2020.11.17; Accepted: 2021.09.30.

*Correspondence: alessandra.aguiar@fiocruz.br; Tel.: +55-41-2104-3231 (A.M.A.).

\section{HIGHLIGHTS}

- Management tools, such as $5 \mathrm{~S}$ and $5 \mathrm{~W} 2 \mathrm{H}$, can be applied to cell culture laboratories.

- The $5 \mathrm{~W} 2 \mathrm{H}$ method allows the prioritization of activities to implement a cell bank.

- The $5 S$ method helps create an organizational routine in a cell culture laboratory.

Abstract: Good cell culture practices are a set of technical and management tools recommended for application in research and service laboratories to guarantee the traceability and reproducibility of in vitro experiments. However, most research laboratories do not have a structured quality assurance system and have difficulties organizing their workflows or even priorities in implementing acceptable laboratory practices. In this study, we applied management and quality assurance tools to define the steps necessary to implement acceptable laboratory practices in the multiuser laboratory of cell culture and establish a cell bank at the Carlos Chagas Institute FIOCRUZ-PR. Our team applied the $5 \mathrm{~W} 2 \mathrm{H}$ and $5 \mathrm{~S}$ tools for initial diagnosis and established an action plan to implement and manage the laboratory over two years. Thereby, we defined the scope of laboratory activities, including the demand for establishing a cell bank, the supply of cell lines to internal users, user training, and quality control tests. We also mapped the main activities, establishing their 
flows and all the necessary documentation to ensure traceability and reproducibility. Additionally, the laboratory was organized in compliance with the $5 \mathrm{~S}$ principles. In conclusion, using management tools, such as the $5 \mathrm{~W} 2 \mathrm{H}$ and $5 \mathrm{~S}$ methods, is a simple and affordable method to organize and manage a cell culture laboratory and can be applied to other research laboratories.

Keywords: cell bank; quality control; cell lineages; reproducibility; good cell culture practices; 5W2H; 5S; quality management.

\section{INTRODUCTION}

The Oswaldo Cruz Foundation (FIOCRUZ), founded in 1900, is an institution that aims to promote health and social development and generate and disseminate scientific and technological knowledge to combat significant public health problems in Brazil [1]. Currently linked to the Ministry of Health, FIOCRUZ carries out activities such as research development, provision of hospital and outpatient reference services in health, manufacture of vaccines, medicines, reagents and diagnostic kits, and human resources training. FIOCRUZ is composed of its head office, located in Rio de Janeiro, 16 technical-scientific units distributed in all regions of Brazil, and an office in Maputo (Mozambique, Africa).

In Curitiba, Paraná, FIOCRUZ is represented by the Carlos Chagas Institute (ICC-FIOCRUZ/PR). The institute was formally founded in 2009, but its activities started in 1999 with the creation of the Institute of Molecular Biology of Paraná (IBMP). In addition to the aims of FIOCRUZ, the purpose of the Paraná unit is to meet the public health demand in the state and develop biomedical scientific research in the areas of biochemistry and molecular and cellular biology [2]. ICC-FIOCRUZ/PR is composed of research and technological development laboratories and offers services of multiuser core facilities, which are available not only to FIOCRUZ's internal community but also to research groups from universities or other institutes of science and technology [3]. For most of these laboratories and core facilities, the use of cell culture is frequently necessary. It is then fundamental to implement, e.g., Good Cell Culture Practice (GCCP), that ensure quality control of cells, enabling laboratories to carry out their research and services with higher quality and reproducibility. Furthermore, in vitro systems are expanding, for use not only in basic research but also in meeting regulatory requirements for new product registrations, including pharmaceuticals [4]. Therefore, maintaining high cell culture quality standards is fundamental for scientific practices and essential for maximizing the reproducibility, reliability, credibility, acceptance, and proper application of any result produced [5,6].

Worldwide, the tendency is to make a centralized, standardized cell distribution system with quality management and traceability to perform in vitro assays with quality. Thus, institutions implement cell banks, among other initiatives, to disseminate the biological material needed for scientific research and development [7]. The cell bank is a storage structure of ampoules with cells preserved under defined conditions, ensuring stability during storage and maintaining the quality of stored cell lines [8]. The creation of a cell bank can be divided into the development of the master cell bank (MCB) to maintain the stock of a cell lineage in the laboratory and in the formation of the working cell bank (WCB) with the cells that are provided for the development of research. Quality control and traceability are essential in all stages to ensure that cells are free of microbial and mycoplasma contamination and have adequate cell viability and proven authenticity $[9,10]$. These traits are ensured by identifying and establishing procedures related to the issues that are most commonly faced in cell culture practices and can arise in multiuser laboratories, including cell culture contamination with microorganisms (mycoplasma, bacteria, fungi and viruses) [11,12], cross-contamination of cell lineages [7], and expired or degraded reagents [12]. Thus, national and international agencies have developed GCCP guidelines to define the minimum standards for guaranteeing the quality of cells and tissue cultures. Such guidelines have been developed by the World Health Organization (WHO), the European reference laboratory for alternatives to animal testing (EURL ECVAM), and other regulatory agencies [13]. The GCCP's main goal is to ensure quality throughout the development of in vitro assays, ensuring efficiency, reproducibility, and robustness of the results obtained with these systems.

The six principles of GCCP involve (1) understanding the cell culture system and the factors that could affect it; (2) ensuring the quality of all methods and materials, aiming to guarantee the integrity, validity, and reproducibility of any study conducted; (3) maintaining the necessary documentation and information to track the methods and materials used, allowing reproducibility; (4) establishing measures to protect individuals and the environment from potential hazards; (5) complying with ethical principles and relevant laws and regulations; and (6) providing adequate education and training to promote high-quality work and safety $[6,14]$. Considering the development of new cell culture methodologies over the years, in 2020, GCCP Guidance 
2.0 was released, including statements related to pluripotent stem cells, 3D cell culture, microphysiological systems (e.g., organ-on-a-chip), and genetically modified cells [14].

The GCCP involves two fundamental aspects: 1) management, related to traceability, records, standardization and quality assurance systems, and 2) the laboratory, with the application of standardized methodologies of cell manipulation, in addition to those related to the quality control of cell cultures (cell characterization and verification of the absence of contaminants) [13]. Among the management tools that can be involved in the implementation of GCCP are the 5W2H and 5S tools. The 5W2H methodology, used in the action planning and decision-making stage, is based on the answers to 7 questions, which provide managerial information through the definitions of responsibilities, methods, deadlines, objectives, and associated resources [15]. The $5 \mathrm{~W} 2 \mathrm{H}$ represents the combination of the initials of the following questions: What?, Why?, When?, Where?, Who?, How?, and How much?. By answering these questions, it is possible to perform a detailed analysis of the process, identifying the priorities, efforts, and resources needed to create a plan of action aimed at its implementation.

Another widely disseminated quality management methodology research laboratories can use is the $5 \mathrm{~S}$ program, which assists in the organization of the work environment [16]. This program emerged in Japan and has goals that involve organizational development, learning, reducing waste, and improving work efficiency [17]. The term 5S is derived from five Japanese words: 1) Seiri refers to keeping what is necessary for the work environment; 2) Seiton relates directly to the ordering of the physical layout facilitating the workflow, eliminating unnecessary movements, and developing a safer environment; 3 ) Seiso denotes the need to keep the environment clean before, during and after activities; 4) Seiketsu aims to provide a higher quality of life for employees through more favorable working conditions; and 5) Shitsuke is responsible for maintaining all phases of the program, which develops the habit of observing and following norms, rules, and procedures [16]. This tool allows the implementation of a laboratory with standardized rules and protocols and, consequently, assists in implementing the GCCP system.

Given the progress of research in Brazil and worldwide, there is a need to establish GCCP systems in research institutions, such as ICC-FIOCRUZ/PR, in which cell culture use is continuously ongoing. For example, the newly established Core Facility for Bioassays in alternative methods in cytotoxicity (ICCFIOCRUZ/PR) needs to ensure criteria for the quality and traceability of the cells used in its tests, and laboratories must follow the specific National Regulation of Good Laboratory Practices [18,19].

Considering the need to standardize the procedures related to cell culture manipulation and quality control, implementing a centralized cell bank system in ICC-FIOCRUZ/PR has gained prominence. Thus, this study's objective was to implement a bank of cell lines at the Carlos Chagas Institute (ICC-FIOCRUZ/PR) following GCCP and to use the $5 \mathrm{~W} 2 \mathrm{H}$ and $5 \mathrm{~S}$ tools to manage quality processes.

\section{MATERIAL AND METHODS}

\section{Quality management procedures}

The action plan for implementing the ICC-FIOCRUZ/PR cell bank was elaborated based on the $5 \mathrm{~W} 2 \mathrm{H}$ tool [15] and the 5S methodology [16]. Based on the seven critical questions of the $5 \mathrm{~W} 2 \mathrm{H}$ tool, the questions related to the project were addressed to assist in the planning and to prioritize activities for the implementation of the cell bank in GCCP. We prioritized inexpensive actions in our planning. Using the $5 \mathrm{~W} 2 \mathrm{H}$ tool and other questions related to the quality control of cell lines according to the Good Laboratory Practices (GLPs) [18] and its complementary document for in vitro tests [19], the action planning presented in Table 1 was performed. Additionally, a diagnosis of the laboratory facilities in which the cell bank was inserted and the cell culture procedures was performed using the 5S methodology, which helped organize space and laboratory routines. 
Table 1. Actions planned for the implementation of the cell bank. Description of the stages and their respective actions to establish a cell bank with quality control. GLP: Good Laboratory Practices, MCB: Master Cell Bank, WCB: Working Cell Bank, QMS: Quality Management System.

\section{Stages}

Initial Diagnosis

Standards Training - GLP and Cell

Culture

5S Program

$5 \mathrm{~W} 2 \mathrm{H}$

Establish the MCB and WCB

Process Mapping

Preparation/Review of QMS Documents

Procedure Training/Documentation Internal Audit

Corrective Actions/Improvement

\section{Main actions}

Identify needs for implementing the quality management system (QMS)

to determine the demands of greater urgency and establish

organizational strategies for the execution of activities.

Know the best practice guidelines to be adopted

Implement practices based on the 5S Program to improve the organization of activities and standardize procedures

Use $5 \mathrm{~W} 2 \mathrm{H}$ in the action planning and decision-making stage, considering the answers to 7 questions that provide managerial information through the definitions of responsibilities, methods, deadlines, objectives, and associated resources

Implement a biorepository to supply cell lines with a known origin, free of microbiological contaminants, and with feasibility control to cellular authentication.

Establish, define the flow of and document the processes and workers responsible for each activity

Standardize processes and document actions based on good practice guidelines applicable to the activities

Standardize the execution of procedures

Check the situation of the laboratory to meet the requirements

Continuously improve processes

\section{Process modeling}

Process modeling, considering the workflow of the Cell Bank laboratory and the services provided for ICC-FIOCRUZ/PR, was developed using an adaptation of the canvas methodology to obtain a basic design. Based on this model, the main services of the cell bank include the development of request forms, deliveries, standard operating procedures (SOPs), quality records (QRs), and other related activities associated with each of the services. Once mapped, the processes were transcribed into a flowchart using the software "BIZAGI MODELER" [20], which allows the graphical representation of the processes involved in a given activity.

\section{Development of standard operating procedures (SOPs) and quality records (QRs)}

Standard operating procedures (SOPs) are documents that provide detailed standardized instructions for activities of a repetitive, routine nature. The establishment of such approved, written working procedures is required by classical quality assurance techniques, indeed, by good management [21]. SOPs and QRs ensure that processes are recorded in a standardized way, enabling training, professionalism, and credibility and ensuring quality through the standardization and traceability of the process.

Therefore, SOPs and QRs were elaborated following the basic guidelines and institutional document format. Each document must be (1) prepared by a person who understands the procedure to be carried out, (2) reviewed by a professional with similar skills to the author and (3) approved by a responsible person. Once approved, the document could be released.

The SOP model applied to this work includes sections related to the protocols and registers, but it also includes sections related to safety procedures, training, and the personal safety equipment (PSE) required to perform the procedures or access laboratory areas. Furthermore, all personnel who access laboratory areas were trained in the biosafety rules and behavior patterns expected in the unit. When needed, outsourced service personnel received all the necessary PSE and were not left unattended.

\section{Demand for users and services}

The need to establish a centralized institutional cell bank following GCCP emerged spontaneously. Additionally, the researchers and collaborators detected the need to offer standardized training to ensure that quality cell cultures were maintained throughout their research. Thus, training services, cell bank preparation, and the supply of cell lines were established. User demands were surveyed for the period from March 2017 to October 2019. 


\section{RESULTS}

\section{Implementation of the 5S methodology in the cell culture laboratory}

Before establishing the cell bank, it was necessary to organize the space in which it would be inserted, a multiuser cell culture laboratory. Thus, for the organization of this laboratory space, the $5 S$ methodology was applied: each of the concepts (Seiri, Seiton, Seiso, Seiketsu, and Shitsuke) was implemented based on the structure necessary for the management of the cell culture laboratory (Figure 1) and considering the limitations of resources (physical space and financial resources), which, once identified, were under constant improvement.

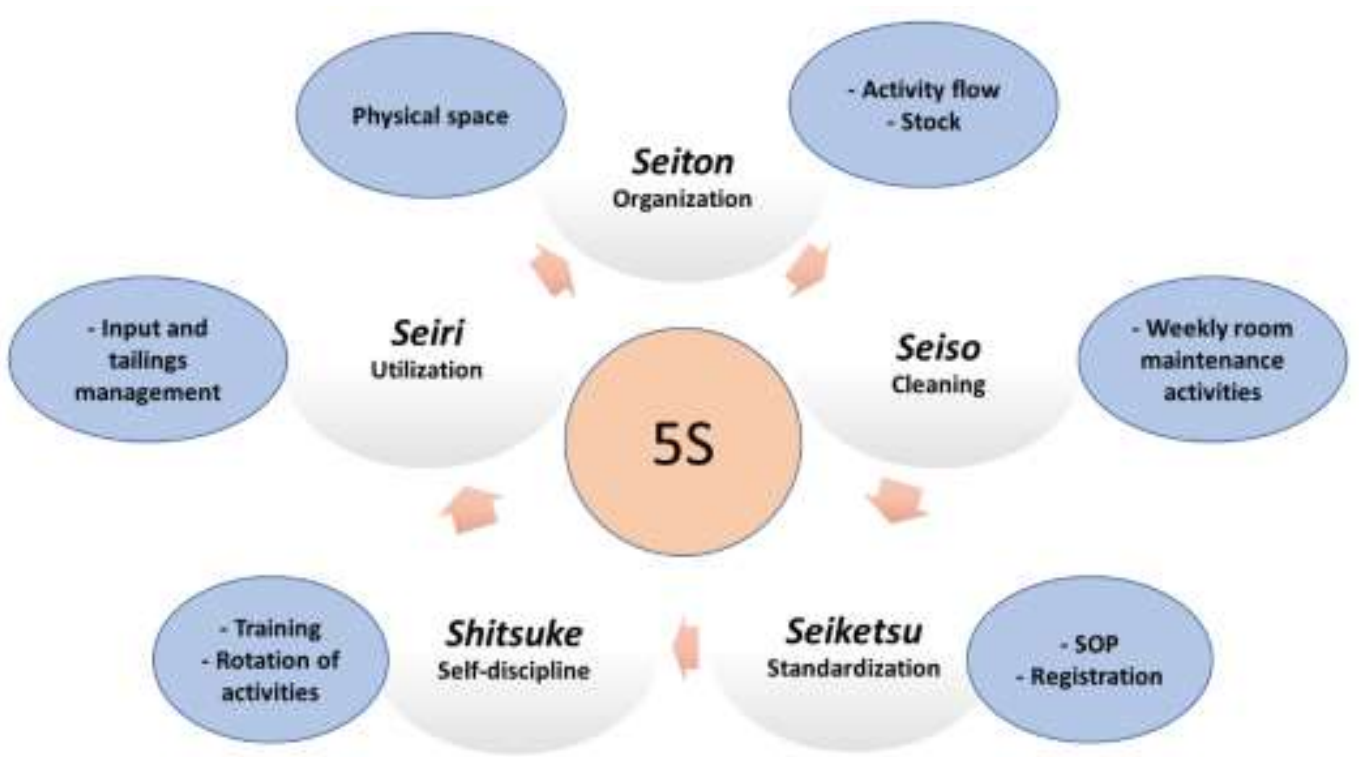

Figure 1. Application of the $5 S$ methodology in the management of the cell culture laboratory. The concepts (Seiri, Seiton, Seiso, Seiketsu, Shitsuke) were mapped according to the activities that must be performed to implement a quality management system that includes disposal, organization, cleaning, standardization, and self-discipline.

The Seiri concept, materials, reagents, and solutions that were not used in the cell culture laboratory were relocated or discarded (following the safety recommendations for each of them), ensuring a clean and organized space. Additionally, the Quartzy platform [22], an online laboratory management system, was used to control the inventory. All available materials were added to this platform, including those located in cabinets, refrigerators $\left(2\right.$ to $\left.8^{\circ} \mathrm{C}\right)$ or freezers $\left(-20^{\circ}\right.$ and $\left.-80^{\circ} \mathrm{C}\right)$. All materials were identified with manufacturer information, product code, expiration date, and quantity available in stock. The database of this management platform is updated weekly. To facilitate registration in the online system and control the received and used materials, the laboratory has a material entry record and a material output record. In the former, the received item is registered, along with the storage location information, while in the latter, the registration includes the reagent and quantity removed from stock. This management system reduced inventory data flaws and allowed the responsible person to purchase laboratory material with greater inventory control. There is also the possibility of configuring the system for issuing alerts when the stock of a reagent reaches the minimum, allowing the orderly planning of materials acquisition and preventing the situation in which experiments need to be stopped for lack of materials. Additionally, the institutional SOP regarding waste management, including the biological and chemical disposal management plan, was applied to the laboratory routine.

Following the Seiton sense, which reflects the workspace organization, the work area layout was established (Figure 2). Before entering the laboratory, there is an anteroom for the operator or other occasional workers allowed in the laboratory, such as the quality assurance team and equipment technicians, to perform hand hygiene and put on the necessary uniform and individual protective items, according to safety guidelines described on SOPs (Figure 2A). In the laboratory, the distribution of equipment follows an organized workflow. There is an area of cell manipulation (Figure 2B), with lab cupboards for the storage and organization of materials and an area for cleaning materials (Figure 2C). Importantly, it is recommended that biological safety cabinets (BSCs) be placed far from the laboratory entry (or door and windows) and from equipment, such as vacuum pumps and centrifuges, which create air movement, to prevent disruption of the air curtain. In addition, if possible, the cabinet should be located in places with less circulation of people, with clear space on each side and behind them to promote good air recirculation [23]. 


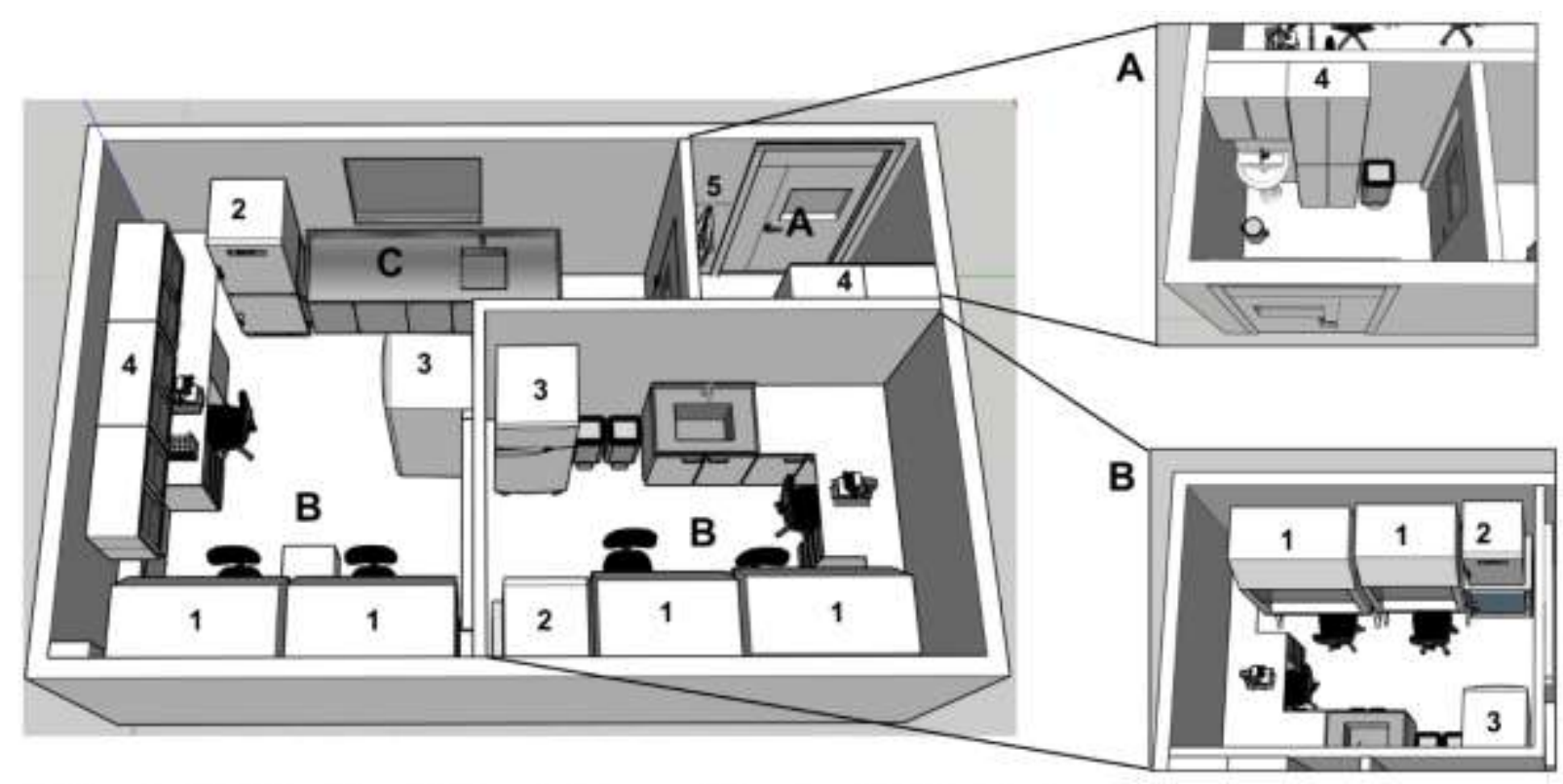

1. Safety cabinet 2. $\mathrm{CO}_{2}$ incubator 3. Retrigerators/ freezers 4. Lab cupboard 5. Lab coat location

Figure 2. Representative images of laboratory areas and disposal of work areas according to their purpose. (A) Anteroom where users wash hands and put on the specific lab coats to enter the next rooms. (B) Handling area. (C) Cleaning area. 1- biological safety cabinets; 2 - CO2 incubators; 3 - refrigerator/freezer; 4 - material storage cabinets; 5 - lab coats.

Additionally, for working conditions to be organized, it is essential to implement the Seiso sense, referring to cleanliness. In cell culture laboratories, one of the main problems is the possibility of cell culture contamination, either by the presence of bacteria and fungi, which are quickly identified, or by the presence of viruses and other microscopic organisms, such as mycoplasma, that cannot be identified through traditional optical microscopy techniques [24]. Therefore, it is essential to control and maintain cleaning and organization conditions. The cell culture reagents (e.g., culture medium) and materials (e.g., culture flasks) were stocked in a separate place, freezer, or refrigerator, and only those that were necessary and in use were maintained in the cell culture laboratory. As our laboratory has multiple users, all employees need to be trained in the maintenance and sanitation of space and equipment. Thus, a routine was implemented in which the users worked in pairs and were responsible for the weekly activities of cleaning and maintaining the laboratory environment. The activities involved replacing plastic and disposable materials, preparing reagents and solutions, and cleaning countertops and equipment, such as incubators and BSCs. In addition to weekly activities, there were biannual activities, such as cleaning/defrosting refrigerators and freezers and deep cleaning and decontaminating BSCs and incubators. We also established the annual certification of BSCs to ensure that the equipment is working correctly. To ensure that the tasks were performed accordingly, the users responsible for the activities were trained according to the SOP regarding the maintenance of the culture room, and all the performed activities were recorded in the corresponding QR.

In a more organized and cleaner environment, we come to the Seiketsu sense, which consists of the possibility of providing a more favorable work environment for employees. This is a reflection of the standardization and preparation of documents, such as SOPs and QRs, in addition to user training and the register of routine activities, such as cleaning, organization of materials and equipment maintenance. Then, with all the senses implanted, we reach the Shitsuke sense, which represents self-discipline. Through user commitment, the laboratory organization and the cell culture standards were successfully maintained. In addition, with continuous training, habits of following the predefined routines and records for organizing and cleaning the laboratory were created and disseminated, which were monitored by the users themselves, focusing on the common good. This indicates that the system established allowed all tasks to be performed in a standardized way by pairs of users each week, with activity records and no work overload. Thus, with the implementation of 5S, the laboratory maintains an organizational structure and creates an adaptation to quality management systems, which represents an opportunity to pave the way for introducing more advanced quality programs. 


\section{Implementation of the $5 \mathrm{~W} 2 \mathrm{H}$ tool in institutional cell bank planning}

After the 5S methodology requirements were applied, a structural plan was developed based on the $5 \mathrm{~W} 2 \mathrm{H}$ tool (Figure 3 ) to prioritize and define the work plan to be executed in implementing the institutional cell bank. For this, the components relative to cost (How Much?) and time (When?) of the 5W2H tool were used as decision-making guidelines. For this work, we prioritized actions that had low cost or required resources that were currently available and actions that could be implemented within two years. Actions that required more significant resources or entailed deployment times of more than two years were not prioritized but were mapped and indicated in future perspectives (Figure 3).

The actions to be performed (What?) were separated into two groups: actions related to quality assurance/management and actions related to laboratory activities and safety. The actors involved (Who?) in developing these actions were defined as the cell bank team, the quality assurance sector, and the managers at ICC-FIOCRUZ/PR. These direct project deliveries (Why?) were divided into establishing the cell bank, providing cell lines, and training users. The necessary activities to achieve these deliveries (How?) were grouped into management/quality assurance activities, such as implementing records and procedures related to GCCP (SOPs, QRs, training), conducting audits and corrective actions, and laboratory activities, such as implementing master and work cell banks with traceability and quality control tests. Regarding location (Where?), all actions were performed in the multiuser cell culture laboratory (shared with the cell bank).

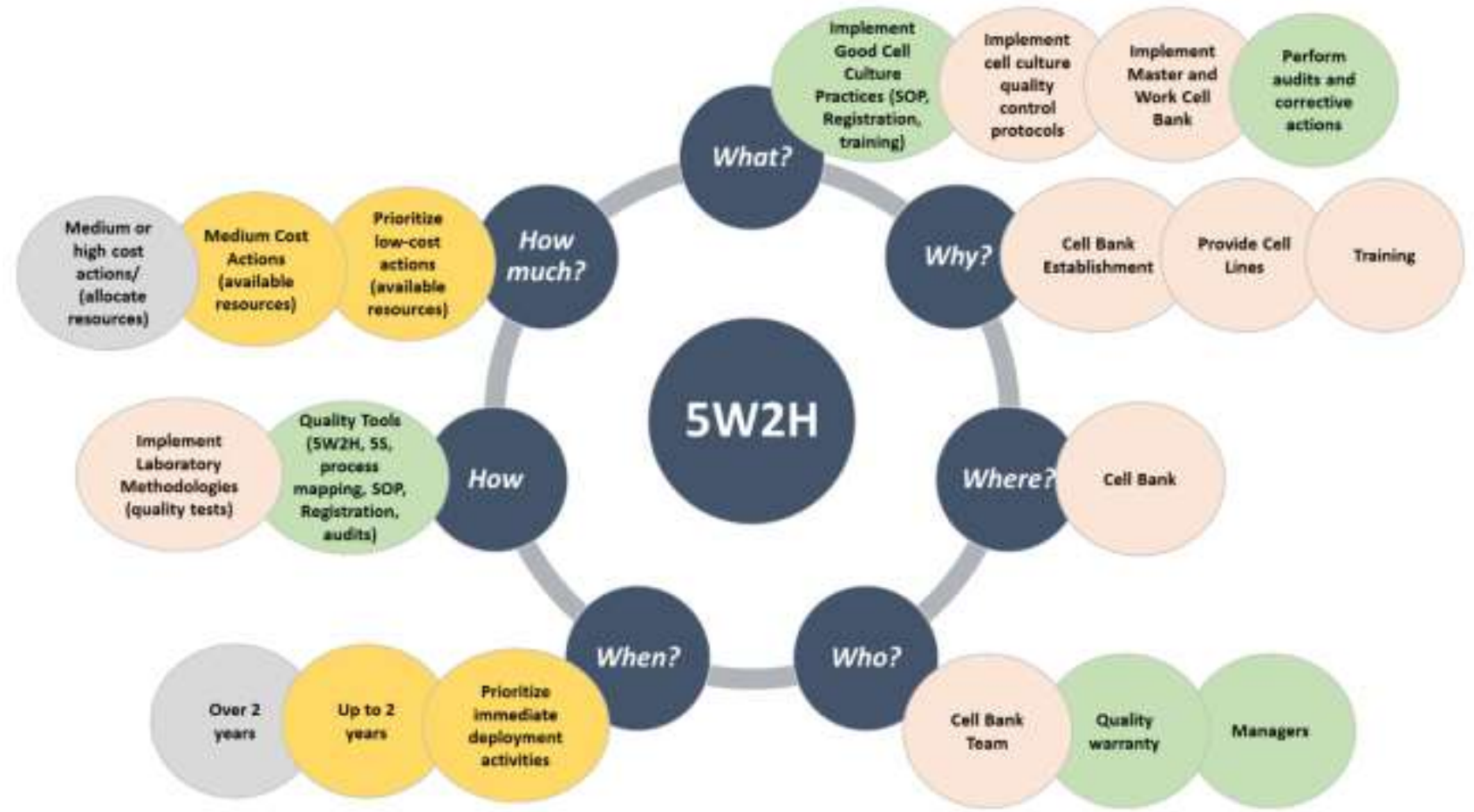

Figure 3. 5W2H matrix applied in the implementation of the ICC Cell Bank. The $5 \mathrm{~W} 2 \mathrm{H}$ matrix (in blue) and the activities related to the implementation of cell bank practices according to GCCP on GLPs and complementary documents on in vitro assays were applied. To guide decision-making regarding the definition of the action plan, items related to cost (how much) and time (when), marked in yellow, were used. Activities that were not prioritized are indicated in gray. The activities related to quality assurance/management are grouped in green, and the actions related to laboratory activities are grouped in pink.

\section{Establishment of the institutional cell bank}

A workflow was followed to implement the institutional cell bank, starting with the receipt of cell lineages until the generation of MCBs and WBCs, including all the necessary quality controls for GCCP (Figure 4). Briefly, when receiving a new cell lineage, the information regarding it (e.g., date of receipt, name of cell lineage, delivery mode, responsible party for the receipt, and other observations) must be recorded in a specific QR, following the guidelines of the SOP "receive lineages. The cells can arrive frozen, in cryovials, or directly in culture vials (Figure 4A). In the first case, the cryovial conditions are first evaluated; e.g., if a cell is frozen, and then cell thawing is carried out, following the cell thawing SOP (Figure 4A). Regarding cells that arrive in culture flasks, it is necessary to visualize them under a microscope to observe the aspect of the cell culture (cell morphology) and indicate contamination with fungi or bacteria (if contaminated, the cells 
must be discarded). After this initial verification stage and with the established cell culture, cells are passaged and expanded, following the SOP of cell passaging, which is registered in a specific QR. In parallel, a cell viability test and tests for mycoplasma detection (following the mycoplasma test SOP and registration in the QR) are performed, aiming to ensure cell quality (Figure 4B). After quality control approval, cells can be expanded and frozen to obtain the MCB. It is necessary to record cryopreservation information by following the QRs. If the culture flask is contaminated (e.g., with bacteria or mycoplasma) or has viability less than $80 \%$, the cells are discarded. After freezing, an evaluation of the quality of thawing (cell viability) is realized by following the instructions of the SOP and specific QR (Figure 4C). After cell viability is confirmed, the cells can be expanded and undergo the same quality controls performed for MCB (Figure 4D) to create the WCB. MCB or WCB cells are available for use only after confirmation of cell viability and negative mycoplasma testing results.

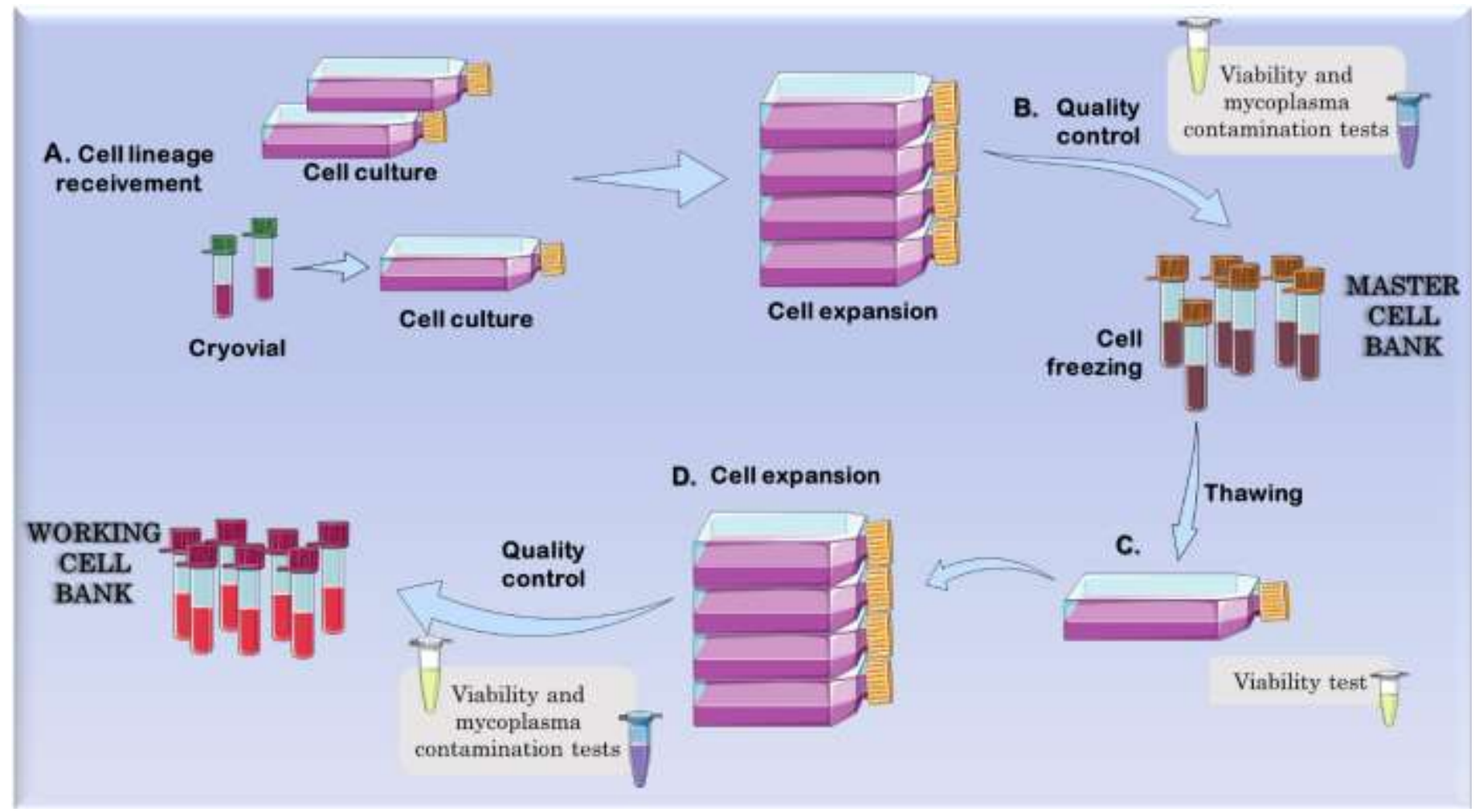

Figure 4. Steps for the establishment of the cell lineage master and working cell bank. The cell lineages could be received in culture flasks or cryovials $(A)$. After initial cell expansion, viability and mycoplasma contamination tests were performed (B) to create the master cell bank (MCB). One MCB cryovial was thawed to assess viability (C), and then the cells were expanded and passed to new quality controls to generate the working cell bank (WCB) (D). The figure was created using images provided by Servier Medical Art (http://smart.servier.com/). Servier Medical Art by Servier is licensed under a Creative Commons Attribution 3.0 Unported License.

The ICC/FIOCRUZ-PR cell bank was initially created for cell lines of higher institutional demand, including Balb/c 3T3 clone A31 cells (ATCC® CCL163TM), V79-4 cells (ATCC® CCL93TM), NHDFs (LONZA, CC-2509), and CHO K1 cells (ATCC® CCL61TM). The number of cryovials in MCB and WCB for each cell lineage was defined based on demand, cell passage, and cost-effectiveness. Information related to these cell lines, such as the specific culture medium, the number of cells to be plated, the cell passage number, and the number of cryovials that compose the MCB and WCB, can be found in Table 2. 
Table 2. Cell lines in the master cell bank (MCB) and working cell bank (WCB) at ICC/FIOCRUZ-PR. The culture conditions (culture medium and $\mathrm{n}^{\circ}$ cells plated in $\mathrm{cm}^{2}$ ) for each cell line and the number of cryovials in the MCB and WCB are described. DMEM: Dulbecco's modified Eagle's medium, RPMI: Roswell Park Memorial Institute (RPMI) 1640 medium, FBS: fetal bovine serum, L-glu: L-glutamine.

\begin{tabular}{|c|c|c|c|c|c|}
\hline \multicolumn{2}{|c|}{ Cell lines } & $\begin{array}{l}\text { Balb/c 3T3 clone } \\
\text { A31 (mouse } \\
\text { embryonic } \\
\text { fibroblast) }\left(\text { ATCC }^{\circledR}\right. \\
\text { CCL163 }^{\mathrm{TM}} \text { ) }\end{array}$ & $\begin{array}{l}\text { CHO K1 (Chinese } \\
\text { hamster ovary cells) } \\
\text { (ATCC }^{\circledR} \text { CCL61 } 61^{\mathrm{TM}} \text { ) }\end{array}$ & $\begin{array}{l}\text { NHDF (normal } \\
\text { human neonatal } \\
\text { dermal fibroblasts) } \\
\text { (LONZA CC-2509) }\end{array}$ & $\begin{array}{l}\text { V79-4 (Chinese } \\
\text { hamster lung } \\
\text { fibroblasts) } \\
\text { (ATCC }^{\circledR} \text { CCL93 }{ }^{\mathrm{TM}} \text { ) }\end{array}$ \\
\hline \multicolumn{2}{|c|}{$\mathrm{n}^{\circ}$ cells $/ \mathrm{cm}^{2}$} & $0,2 \times 10^{4}$ & $0,5 \times 10^{4}$ & $0,2 \times 10^{4}$ & $0,2 \times 10^{4}$ \\
\hline \multicolumn{2}{|c|}{ Culture medium } & $\begin{array}{l}\text { DMEM } 10 \% \text { FBS }+1 \% \text { L } \\
\text { glu }\end{array}$ & $\begin{array}{l}\text { L RPMI } 10 \% \text { FBS }+1 \% \\
\text { glu }\end{array}$ & $\begin{array}{l}\text { DMEM } 10 \% \text { FBS + } \\
1 \% \text { L-glu }\end{array}$ & $\begin{array}{l}\text { DMEM 10\% FBS + } \\
1 \% \text { L-glu }\end{array}$ \\
\hline \multirow{2}{*}{ MCB } & Cell passage & 89 & $3^{*}$ & 4 & 25 \\
\hline & $n^{\circ}$ cryovials & 9 & 17 & 28 & 36 \\
\hline \multirow{2}{*}{ WCB } & Cell passage & 91 & $6^{*}$ & 6 & 28 \\
\hline & $\mathrm{n}^{\circ}$ cryovials & 15 & 18 & 21 & 36 \\
\hline
\end{tabular}

${ }^{*}$ Not specified by provider. Passage number attributed locally.

\section{Implementation of GCCP in the cell culture laboratory}

After the centralized cell bank was established, it became the responsibility of the bank's technical manager, who has knowledge and more than 10 years of experience in cell culture, to train users of ICCFIOCRUZ/PR in cell culture techniques and ensure the standardization of procedures and cell quality. The first step to guaranteeing that all employees were trained in standard procedures was preparing the SOPs (also the responsibility of the technical manager of the cell bank). The SOPs are available both in the laboratory and online (via intranet) for free access. The prepared SOPs and QRs were related to the preparation of solutions and materials for animal cell culture, cell freezing and thawing, receipt control of cell lineages, passaging of animal cells, and maintenance of the cell bank.

For GCCP to be disseminated, it is critical that the users, regardless of their level of experience, are trained according to the SOPs. Therefore, every new employee must follow the flow mapped in Figure 5A. Initially, both the students and their advisors request training from the cell bank manager, who schedules the days of training (with 1 or 2 weekly activities, with 2 to 3 hours each). Basic training consists of reading SOPs associated with practical activities that include cell thawing, cell passage, cell counting, and cell freezing. The users initially accompany and observe the instructor (cell bank manager), and then they perform the activities. Finally, a practical evaluation is made, according to the cell bank manager and SOP instructions, before the user is allowed to act autonomously in the cell culture laboratory. All the training phases are recorded in QRs.

From March 2017 to October 2019, 27 employees, including undergraduate, master's, and doctoral students; employees; and others, such as scholarship holders, were trained and used the cell culture laboratory (Figure 5B). All these users, independent of their educational degree, were trained using the same methodology. Interestingly, more than $65 \%$ of the trained users were in the categories usually associated with the beginning of a scientific-academic career, including undergraduate and master's degree students. This fact indicates the importance of our training, which was focused not only on technical-scientific training but also on the organizational culture based on the $5 \mathrm{~S}$ methodology in terms of human resources.

A

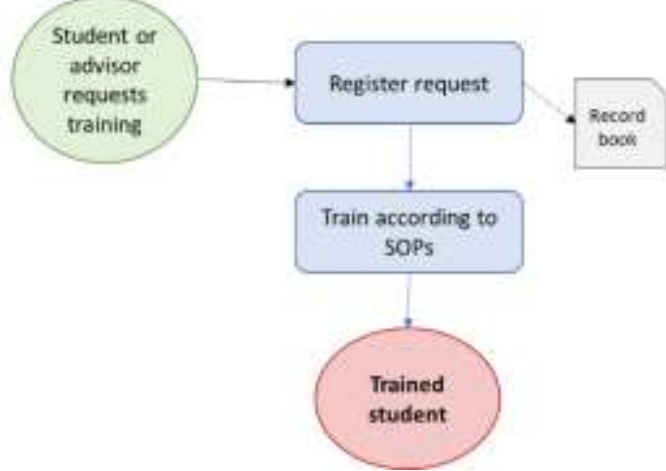

B

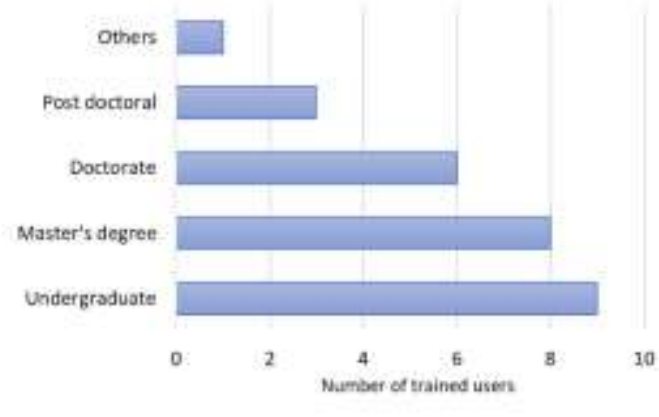

Figure 5. Training of new students and employees of the institution. (A) Flowchart of the training process. Each user requests training from the cell bank manager, who monitors the user's development and protocol execution until the user can perform the activities alone. (B) Graphic representation of trained users, according to institutional link. Data for the period from March 2017 to October 2019. 


\section{DISCUSSION}

The quality and reproducibility of scientific results is a fundamental requirement for any research, diagnostic work, or manufacturing process and is at the core of GCCP. To ensure this, simple management methodologies can be applied to improve laboratory practices. Implementing a cell culture laboratory with quality is essential to maximize the reproducibility, reliability, credibility, acceptance, and proper application of any results produced $[5,6,14]$. Thus, through an internal institutional evaluation, the need to establish a cell bank in ICC-FIOCRUZ/PR, planned and structured to operate within a quality assurance system, was observed. Based on this demand, a quality management system was implemented based on the $5 \mathrm{~W} 2 \mathrm{H}, 5 \mathrm{~S}$, and GCCP to ensure standard working conditions among all users, with improved organization and traceability.

The $5 \mathrm{~W} 2 \mathrm{H}$ and $5 \mathrm{~S}$ tools are already widely used in other management contexts, such as small businesses, and are even part of the small business training strategy [25]. However, their use in the laboratory context is still little explored. The 5S methodology allowed us to organize the laboratory environment, including users in responsibilities such as cleaning and spatial organization. Among the approaches performed, we highlight the establishment of pairs of users responsible for organizing and cleaning the laboratory each week and biannual cleanings. This strategy proved to be very useful in maintaining the cell culture laboratory since the laboratory was kept clean and tidy, with the materials and reagents necessary for cell culture always available. This allowed for a better workflow and decreased the chance of cell culture contamination.

It was also noted that the implementation of the inventory management system allowed better use of materials. With this online management system, students and collaborators could manage their research and communicate the demand for new materials in advance. Purchasing and inventory management is a critical and essential component within a quality management system because, for an efficient and economical laboratory, the availability of reagents, supplies, and services must be uninterrupted and generate no waste. The inability to perform experiments, even for a short time, can be very damaging to research. In Brazil, many imported products take months to deliver. In some cases, the delay in receiving the product is related to customs clearance by national regulatory agencies, such as the National Health Surveillance Agency (ANVISA) [26].

Together with all these strategies of the 5S methodology, which can directly impact the quality of cell culture by, for example, preventing microbiological contamination and cross-contamination between cell lines, the $5 \mathrm{~W} 2 \mathrm{H}$ tool was used to assist in implementing the cell lineage bank. This tool enabled the design of an action plan to establish the institutional cell bank, showing the priorities and activities related to the bank and its responsibilities. Among the laboratory activities stand out the establishment of the cell bank, the supply of cell lines, and user training, while in the management part, standardized systems of methodologies that allow the traceability of processes were constructed. These activities may also represent a cost reduction. The costs caused by the lack of reproducibility are reduced if there are procedures to improve traceability and an equipment maintenance plan, reducing the need to repeat experiments.

The development of MCB and WCB followed the planning established by the $5 \mathrm{~W} 2 \mathrm{H}$ tool and $5 \mathrm{~S}$ principles, including standards and recommendations of GCCP and developing controls for traceability and ensuring the quality of cell lines. The correlation of the $5 S$ and GCCP principles is outlined in Table 3 . This summary shows how it is possible to correlate both tools to improve cell culture practices. Thus, following these standards, a cell bank was created for four cell lineages, which can be used in various types of research $[27,28]$. In addition to ensuring traceability, all cell cultures were tested, as recommended, to ensure that cells remained viable and without mycoplasma contamination [6,29]. Mycoplasma contamination could alter different aspect of cellular behavior, including inhibition of cell proliferation, change in cell morphology, metabolism and gene expression, induction of chromosomal aberrations, and cell death [30,31]. Although the cell lineages are released for use only after confirmation of cell viability and a negative result for the mycoplasma test, other precautions can be taken. We apply procedures to minimize contaminations, such as do no share culture media or any other solution for diverse cell lines, we do not manipulate different cultures simultaneously, and we clean the BSC before and after each use. Additionally, for example, an environment (room, incubator, BSC) can be established for the exclusive use of new cell lineages as a quarantine period to prevent contamination.

All procedures related to cell culture and cell banking were documented. According to Geraghty and collaborators, establishing SOPs for the laboratory is very important to guarantee the quality of processes due to the standardization of methodologies, with user training associated with traceability and the use of specific records for each activity [29]. Six SOPs and 12 QRs were formalized for this study, which were and 
long terms, actions could also affect the reproducibility of experimental results and immediately applied in the laboratory's routine. Several users were trained in these management methodologies. Although difficult to measure, the improvements after implementing the standardized training in cell culture procedures, associated with the laboratory organization instructions, may be related to the low microbiological contamination index of cell cultures and, consequently, material savings. In the medium the standardization of cell culture procedures/protocols throughout ICC-FIOCRUZ/PR. These practices should then reduce and prevent the risks of these adverse events in cell culture practices in multiuser laboratories, preventing the loss of cell cultures due to contamination, mislabeling, or the use of degraded culture reagents caused by many factors related to the expiration date or wrong procedures for preparing or stocking the reagents.

Table 3. Correlation of the 5S Principles and the GCCP Principles based on [6,14]. Description and expected impacts on cell culture laboratories.

\section{SEIRI: Sense of Use}

\section{Sense Description}

Refers to the disposal or relocation of everything considered unnecessary for carrying out the activities.
GCCP Principles

1 and 4

\section{Expected results in laboratory}

- Space gain;

- Ease of cleaning and maintenance;

- Cost reduction;

- Preparation of the environment for the application of other $5 S$ concepts.

\section{SEITON: Sense of Organization}

\section{Sense Description}

Refers to accessing everything needed quickly and effectively. The identification of cabinets and drawers, freezers or refrigerators, and equipment distribution in an organized workflow are strategies to organize the environment.
GCCP Principles

2 and 4

\section{Expected results in laboratory}

- Time saving;

- Easy location of tools and materials;

- Reduction of unsafe points.

- Better control of stocks (use of online management system).

\section{SEISO: Sense of Cleanliness}

\section{Sense Description}

Refers to the importance of maintaining the cleanest environment possible before, during, and after activities.
GCCP Principles

1 and 4

\section{Expected results in laboratory}

- Healthy and pleasant environment;

- Reduction of the possibility of accidents;

- Better conservation of tools and equipment;

- Improvement in interpersonal relationships.

\section{SEIKETSU: Sense of Standardization}

\section{Sense Description}

Refers to the possibility of providing a more favorable work environment for employees, which is a reflection of all standardization.
GCCP Principles

$1,2,3,5$ and 6

\section{Expected results in laboratory}

- Ease of locating and identifying objects and tools;

- Preparation of POP and RQ;

- User training.

\section{SHITSUKE: Sense of Self-discipline}

\section{Sense Description}

Refers to the commitment of the users, where all tasks are successfully maintained.
GCCP Principles

$1,3,5$ and 6

\section{Expected results in laboratory}

- Better quality, productivity and safety at work;

- Enjoyable daily work;

- Improvement in human relations;

- Valuing the human being;

- Compliance with operating procedures. 


\section{CONCLUSION}

This study showed how using $5 \mathrm{~W} 2 \mathrm{H}$ and $5 \mathrm{~S}$ management tools could contribute to planning the implementation, for example, of a cell bank. Based on the $5 \mathrm{~W} 2 \mathrm{H}$ tool, it was possible to diagnose the needs for structuring the cell bank over 2 years using the available institutional resources. On the other hand, the actions implemented with the 5S methodology helped create an organized cell culture laboratory in which users follow the rules established for the environment. Additionally, through training using SOPs and QRs created for cell culture, the procedures began to be standardized.

Funding: CNPq Universal 2018 process number 426063/2018-0.

Acknowledgments: The authors would like to thank Carlos Chagas Institute and the Program for Technological Development in Tools for Health (RPT-FIOCRUZ) for use in the facilities and materials used for the experiments. We also thank the staff of Carlos Chagas Institute for administrative and technical support, the members of Basic Stem Cell Biology Laboratory and Andrea Avila for helpful discussions, Isabelle Leticia Zaboroski Silva and Adriane Emi Shibukawa for revising the manuscript, Claudio Michelle Ciotti for process mapping, Danielle Dias Marques Franco for 3D design and Wagner Nagib de Souza Birbeire for graphic design.

Conflicts of Interest: The authors declare no conflicts of interest.

\section{REFERENCES}

1. FIOCRUZ. Relatório de gestão do exercício de 2018. Fundação Oswaldo Cruz. 2018;

2. icc.fiocruz.br. Instituto Carlos Chagas - FIOCRUZ/PR [Internet]. [cited 14 Nov 2020]. Available: https://www.icc.fiocruz.br/

3. portal.fiocruz.br. FIOCRUZ - Fundação Oswaldo Cruz [Internet]. [cited 14 Nov 2020]. Available: https://portal.fiocruz.br/

4. Granjeiro JM, Delgado I, Labarthe N. Advanced cellular technologies : biotechnology and regulatory challenges. Visa em Debate. 2018;6: 1-5.

5. Freedman LP, Gibson MC, Ethier SP, Soule HR, Neve RM, Reid YA. Reproducibility: Changing the policies and culture of cell line authentication. Nat Methods. 2015;12: 493-497. doi:10.1038/nmeth.3403

6. Coecke S, Balls M, Bowe G, Davis J, Gstraunthaler G, Hartung T, et al. Guidance on good cell culture practice: A Report of the Second ECVAM Task Force on good cell culture practice. ATLA Altern to Lab Anim. 2005;33: 26187. doi:10.1177/026119290503300313

7. OECD. Guidance Document on Good In Vitro Method Practices (GIVIMP), OECD Series on Testing and Assessment. OECD Publishing. Paris; 2018.

8. Stacey GN, Masters JR. Cryopreservation and banking of mammalian cell lines. Nat Protoc. 2008;3: 1981-1989. doi:10.1038/nprot.2008.190

9. Cobo F, Stacey GN, Hunt C, Cabrera C, Nieto A, Montes R, et al. Microbiological control in stem cell banks: Approaches to standardisation. Appl Microbiol Biotechnol. 2005;68: 456-66. doi:10.1007/s00253-005-0062-2

10. Lorge E, Moore MM, Clements J, O'Donovan M, Fellows MD, Honma M, et al. Standardized cell sources and recommendations for good cell culture practices in genotoxicity testing. Mutat Res - Genet Toxicol Environ Mutagen. 2016;809: 1-15. doi:10.1016/j.mrgentox.2016.08.001

11. Knight LA, Cree IA. Quality Assurance and Good Laboratory Practice. 2011;731: 115-124. doi:10.1007/978-161779-080-5 10

12. Pamies D, Bal-Price A, Chesné C, Coecke S, Dinnyes A, Eskes C, et al. Advanced Good Cell Culture Practice for human primary, stem cell-derived and organoid models as well as microphysiological systems. ALTEX. 2018;35: 353-378. doi:10.14573/altex.1710081

13. Eskes C, Boström AC, Bowe G, Coecke S, Hartung T, Hendriks G, et al. Good cell culture practices \& in vitro toxicology. Toxicol Vitr. 2017;45: 272-7. doi:10.1016/j.tiv.2017.04.022

14. Pamies D, Leist M, Coecke S, Bowe G, Allen D, Gstraunthaler G, et al. Good Cell and Tissue Culture Practice 2.0 (GCCP 2.0) - Draft for stakeholder discussion and call for action. ALTEX. 2020;37: 490-2. doi:10.14573/altex.2007091

15. Marshall Junior I, Cierco AA, Rocha AV, Mota EB, Leusin S. Gestão da Qualidade. Rio de Janeiro: FGV; 2008.

16. Gapp R, Fisher R, Kobayashi K. Implementing 5 S within a Japanese context: An integrated management system. Manag Decis. 2008;46: 565-79. doi:10.1108/00251740810865067

17. Jaca C, Viles E, Paipa-Galeano L, Santos J, Mateo R. Learning 5 S principles from Japanese best practitioners: Case studies of five manufacturing companies. Int $J$ Prod Res. 2014;52: 4574-86. doi:10.1080/00207543.2013.878481

18. ANVISA - NIT-DICLA-035. Princípios das boas práticas de laboratório. 2019 p. 16.

19. ANVISA - NIT-DICLA-071. Princípios das BPL e estudos in vitro. 2019 p. 14.

20. Bizzagi Modeler [Internet]. Available: https://www.bizagi.com/pt/plataforma/modeler

21. OMS, Organização Mundial da Saúde (World Health Organization). Manual: práticas de qualidade na pesquisa biomédica básica. 22nd ed. Belo Horizonte; 2010.

22. quartzy.com. No Title [Internet]. [cited 15 Nov 2020]. Available: www.quartzy.com 
23. $\mathrm{CDC} / \mathrm{NIH}$. Biosafety in Microbiological and Biomedical Laboratories, 6th Edition, Revised June 2020. 2020; 1-574. Available: https://www.cdc.gov/labs/pdf/SF_19_308133-A_BMBL6_00-BOOK-WEB-final-3.pdf

24. Corral-Vázquez C, Aguilar-Quesada R, Catalina P, Lucena-Aguilar G, Ligero G, Miranda B, et al. Cell lines authentication and mycoplasma detection as minimun quality control of cell lines in biobanking. Cell Tissue Bank. 2017;18: 271-80. doi:10.1007/s10561-017-9617-6

25. SEBRAE. 5W2H: tire suas dúvidas e coloque produtividade no seu dia a dia [Internet]. [cited 14 Nov 2020]. Available: https://www.sebrae.com.br/sites/PortalSebrae/artigos/5w2h-tire-suas-duvidas-e-coloque-produtividadeno-seu-dia-a-dia, 06731951b837f510VgnVCM1000004c00210aRCRD

26. INTERFARMA. Levantamento revela que a burocracia para importar material barra o avanço da ciência no Brasil [Internet]. [cited 14 Nov 2020]. Available: https://www.interfarma.org.br/noticias/554

27. OECD. Guidance document on using cytotoxicity test to estimate starting doses for acute oral systemic toxicity tests. OECD Guidel Test Chem. 2010;July: 1-54.

28. OECD. Guideline for the testing of chemicals. 2014;487: 1-16.

29. Geraghty RJ, Capes-Davis A, Davis JM, Downward J, Freshney RI, Knezevic I, et al. Guidelines for the use of cell lines in biomedical research. Br J Cancer. 2014;111: 1021-46. doi:10.1038/bjc.2014.166

30. Drexler HG, Uphoff CC. Mycoplasma contamination of cell cultures: Incidence, sources, effects, detection, elimination, prevention. Cytotechnology. 2002;39: 75-90. doi:10.1023/A:1022913015916

31. Nikfarjam L, Farzaneh P. Prevention and detection of mycoplasma contamination in cell culture. Cell J. 2012;13: 203-12.

2021 by the authors. Submitted for possible open access publication under the terms and conditions of the Creative Commons Attribution (CC BY NC) license (https://creativecommons.org/licenses/by-nc/4.0/). 